\title{
- $\quad$ PLANNING IN TURBULENT TIMES: Exploring Planners' Agency in Jerusalem
}

\author{
JONATHAN ROKEM AND MARCO ALLEGRA
}

\begin{abstract}
This article explores the role of planning in the deeply divided and politically polarized context of Jerusalem. The overall argument developed throughout the article is that the relation between planning and politics is a non-hierarchical set of interactions, negotiated within specific historical, geographical, legal and cultural contexts-in other words, orders don't come down from the politicians to be slavishly followed by planners. In this respect our findings, based on in-depth interviews with Israeli planners, suggest that the case of Jerusalem represents a particularly dramatic illustration of the fact that the function of planning expertise can only be understood in relation to the surrounding socio-political environment. Furthermore, contrary to conventional wisdom, planners in Jerusalem are not destined to either complicity or irrelevance in the face of political imperatives; planners' agency, however, does not simply reflect their mastery of specific professional knowledge and tools, but also their ability to act strategically in relation to the context in which they operate.
\end{abstract}

\section{Introduction}

How do planners operating in a contested city make sense of the polarized environment in which the planning system functions? How do they reconcile their role as professionals with the existence of partisan policy goals and harsh power asymmetries? And to what extent can planners have an impact in such a deeply polarized contextwhere, the argument goes, planning is subordinated to political considerations? This article tries to answer these questions about the relation between planning and politics through an exploration of the experience of Israeli planners in the city of Jerusalem. The overall argument developed throughout the article is that an appreciation of the contextual nature of planning practices is crucial to further our understanding of the relation between planning and politics as a non-hierarchical set of interactions, negotiated within historical, geographical, legal and cultural contexts-and, specifically, to make sense of the agency of Israeli planners in relation to the entanglement of planning and political issues in Jerusalem.

Our study of Jerusalem offers two distinct but interrelated insights. First, it reminds us in a particularly dramatic way that urban planning issues are more broadly political and social issues. This does not only mean that planners face concerns that go beyond the narrow limits of their professional training or the responsibilities inherent in their institutional role; crucially, it also means that the function of planning expertise can only be assessed in relation to the socio-political environment in which the planning system operates. Second, we argue that, contrary to conventional wisdom, planning in Jerusalem is not destined to either complicity or irrelevance in the face of political imperatives. Planners do have agency, but any assessment of this agency depends on the acknowledgement that it is impossible to draw a neat or arbitrary boundary between 'planning' and 'politics'. Planners' contribution to the policy process does not simply reflect their mastery of specific professional knowledge and a set of tools, but also their ability to act strategically in relation to the context in which they operate; at

The authors rendered equal contribution to the article. We want to thank Margo Huxley for her important comments on earlier versions of the article and also the three anonymous IJURR reviewers for their valuable feedback. 
the same time, there is a reciprocal influence between the dynamics of the planning process and the surrounding socio-political environment.

The bulk of the empirical material for this study is constituted by in-depth interviews with Israeli planners. The next section of the article illustrates the theoretical background of the analysis, especially in relation to wider debates in planning theory. In the third section, we briefly introduce the reader to the environment of Jerusalem, in order to present the structural challenges to planners' actions in the context of a contested city. The fourth section of the article describes the experience of planners with respect to the polarization of the urban environment, and their personal and professional strategies to cope with the challenges inherent to this situation. In the final section we offer a few concluding remarks.

\section{The politics of planning}

The relation between planning and politics has been central to the debate in planning theory for decades. Since the early 1990s, this debate has largely developed in reaction to the success of the 'communicative' or 'collaborative' approaches to planning. Drawing on Jurgen Habermas' $(1979 ; 1989 ; 1990)$ work on deliberative rationality and on Anthony Giddens' (1984) structuration theory, scholars such as John Forrester (1982; 1988; 1993; 1999; 2009), Patsy Healey (1992; 1996; 1997) and Judith Innes (1995) have focused on the mechanics of discursive and deliberative practices, and on the achievement of consensus amongst participants in order to remove imbalances and negative effects of power asymmetries in the planning process (for a review see Healey, 2012). Their critics, in turn, have challenged the Habermasian/Giddensian roots of communicative theory by referring especially to the work of Michel Foucault (1979; $1980 ; 1983 ; 1984)$ and Chantal Mouffe (1999; 2000; 2005).

The theory of communicative planning (itself a wide and diverse body of literature) has become the testing ground for debating a number of crucial issues for social sciences as a whole. Critics of communicative planning have debated the ontological foundations of (democratic) planning praxis (Bond, 2011; Gualini, 2015) as part of a wider argument on alternative conceptions of democratic politics (Flyvbjerg, 1998a; Purcell, 2008; Silver et al., 2010); models of rationality underlying different streams of planning theory and their analytical and normative goals have also been subject to debate (Flyvbjerg, 1996; 1998b; Flyvbjerg and Richardson, 2002); as have the relations between process and context (Lauria and Whelan, 1995; Fainstein, 2000; Yiftachel and Huxley, 2000b; Fainstein, 2010) and the dialectic between analytical and normative ambitions of planning theory (Yiftachel and Huxley, 2000a; 2000c). Further critical discussions have taken place around the relation between the theoretical corpus of communicative scholarship and actual experiences of planning practices and processes (Tewdwr-Jones and Allmendinger, 1998) and the emancipatory progressive potential often attributed to planning practices (Flyvbjerg, 1996; Yiftachel, 1998; Porter, 2010: 125-50). And, in general, the theoretical status and ambitions of the body of work of communicative scholars has been examined in the light of other approaches to planning theory, urban studies and political geography (Huxley and Yiftachel, 1998; Yiftachel and Huxley, 2000b). The debate has remained lively and to a certain extent polarizing, to the point that some scholars conclude that: 'Planning theory seems to have become a set of dividing discourses' (Innes and Booher, 2014: 196). Despite some efforts to bridge the gap (Hillier, 2002; Bond, 2011), the existence of unresolved ontological, epistemological and normative tensions suggests it would be naïve to think that a comprehensive synthesis between the different positions can be found.

The debates we have alluded to, however, can serve as a background to illustrate and clarify the purpose of this article which, first and foremost, is an attempt to offer an empirically grounded characterization of the relation between planning and politics in Jerusalem. Nevertheless, we maintain that our emphasis on the situated nature of 
planning practices can provide some more general insights in this respect, and suggest ways in which the gap between communicative theorists and their critics can be narrowed and, most importantly, reinterpreted in an analytically productive fashion.

Broadly speaking, it has been suggested that considering temporal and spatial contexts of planning intervention (and, more generally, of urban policies) can blur the differences between dichotomies in understandings of the Habermas/Foucault divide in relation to urban democracy and planning practices (Pugh, 2005; Beaumont and Loopmans, 2008; Silver et al., 2010; Bond, 2011). In particular:

distinctions between consensus and conflict, top down and bottom up, do not constitute mutually exclusive categories ... Rather than propose a compromise or 'hybrid' type of democracy ... or simply view contestation and consensus as mutually exclusive alternatives, we see opposing normative conceptions of democracy as different 'moments' in the democratic process (Silver et al., 2010: 454).

On the other side, since the beginning of the 1990s, social sciences have abandoned the long-held positivistic notion of expertise as a neutral, rational and readymade resource, in favour of the so-called 'argumentative' turn of policy enquiry (Hoppe, 1999). Also thanks to key contributions by communicative theorists (Fischer and Forester, 1993) planning professionals are today largely seen as belonging to the category that Frank Fischer (2009: 11) defines as 'post-empiricist experts', as mediators 'operating between the available analytic frameworks of social science, particular policy findings, and the differing perspectives of the public actors'. At the same time, while many communicative theorists (e.g. Forester, 1999; 2009; Fischer, 2009) have analysed the role of experts with the aim of defining a set of good professional practices, both their critics (Flyvbjerg, 1996; 1998b) and scholars belonging to the same argumentative/ deliberative tradition (Wagenaar, 2004) have pointed out that experts commonly resort to practical judgments, coalition building, lobbying and political activism-in short, they make strategic use of their professional knowledge and status to steer the policy process.

Our emphasis on conceiving planning as a relational and non-hierarchical set of interactions and negotiations builds on these suggestions in two ways: through broad argument about the debate in planning theory; and in two propositions derived from our research on Jerusalem.

First, we suggest that in many cases the rift between communicative scholars and their critics can be productively reformulated in terms of their emphasis on two different contexts or moments in which the relation between planning and politics is played out. Communicative scholars largely focus on the 'politics in planning' (i.e. how issues of power and conflict play a role in the planning process) and place their emphasis (sometimes with strong normative undertones) on the role of the deliberative practitioner in this context. Their critics focus instead on the 'politics of planning' (i.e. the broader social and political structures in which planning processes take place) with the ambition of developing the analytical task of examining aspects of planning policies and practices that can be seen to operate as forms of 'socio-spatial engineering'.

While this distinction remains meaningful in many ways, we maintain that both dimensions are relevant in furthering our understanding of the relation between planning and politics. Indeed, while the critics of communicative theory have correctly noted how a purely procedural approach to planning obscures the decisive influence of the surrounding socio-political environment on the dynamics of the planning process,

1 This tension is vividly expressed in the exchange between John Forester (2000), Patsy Healey (2000) and Oren Yiftachel and Margo Huxley (2000a), published in 2000 in IJURR. 
communicative scholars have not been totally blind to this dynamic (see e.g. Healey, 2006; 2013). In particular, Healey (2003: 109) has argued that the communicative emphasis on ethnographic accounts of planning practices can be justified in the light of the fact that innovations are occurring all the time in the fine grain. In certain circumstances, these have the potential to challenge the driving forces to which local initiatives find themselves subject'-a position that echoes the notion of 'insurgency' (Holston, 2008) and the call to learn from 'marginalized' local voices to enrich planning theory and practice (Sandercock, 1998). The need to consider both the external and internal dynamics of the relation between planning and politics experienced by planners in Jerusalem is critical in grasping the full complexity of their agency.

Second, we argue that, as far as this relation is concerned, Jerusalem represents both an 'extreme' and a 'critical' case. It is an 'extreme case'-i.e. a case that makes a point in 'an especially dramatic way' (Flyvbjerg, 2006: 229)-because it emphasizes the importance of taking into account the dynamics of local power relations in the planning process. Observing planners in Jerusalem not only makes it clear that the sociopolitical context constitutes a structure of constraints and opportunities for planners' agency, but also that the very definition of what constitutes 'good planning practices' depends on this context. Indeed, the consensus on the very idea of 'good planning practices' is more apparent than real among planners in Jerusalem; ultimately, ideals of 'good planning' do not represent abstract commentaries on the role of planning, but rather manifestations of specific (and not necessarily consensual) forms of contingent limited rationality-what Flyvbjerg (1996) defines in terms of Realrationalität. Jerusalem also represents a 'critical case'-i.e. a case intended to achieve information that permits logical deductions of the type, 'If this is (not) valid for this case, then it applies to all (no) cases' (Flyvbjerg, 2006: 230)-with respect to planners' agency. In other words, if we are able to demonstrate that planners do have an influence on urban issues in Jerusalem-where, it is widely assumed, planning is subordinated to politics - then this holds true, a fortiori, for less polarized urban contexts. Having said that Jerusalem contains extreme power dynamics with the potential of theoretically linking diverging planning discourses, we now move on to how the geopolitical reality has shaped planning in the city.

\section{Jerusalem-planning and urban geopolitics in a contested city}

The partisan nature of planning in Jerusalem is widely recognized-and indeed, the city is placed firmly in the literature on 'contested' cities (Kliot and Mansfeld, 1999; Kotek, 1999; Bollens, 2000; Anderson, 2008; Rosen and Shlay, 2010; 2014; Silver, 2010; Calame and Charlesworth, 2011) - for a review see Allegra et al. (2012). In Jerusalem, past and continuing conflicts between Israelis and Palestinians have created a situation where the very existence of the system of governance is contested by a large part of the population, and where the planning system as a whole lacks widespread legitimacy, instead playing a major role in exacerbating spatial and social divisions. The scholarly literature has produced countless accounts of the asymmetries inherent in Israeli planning policies in the city (for some recent examples, see Dumper, 2014; Shlay and Rosen, 2015; Rokem, 2016a). It is not our intention to list and describe the many episodes and facets of the politicization of planning in Jerusalem: however, in order to relate our exploration of planning practices to their contents, context and scale, we will attempt in this section to understand how these extreme urban geopolitical conditions created a set of opportunities and constraints for Israeli planners.

Since reunification of the city in 1967 , territorial and demographic concerns over the status of Jerusalem have been paramount in determining planning decisions (Rokem, 2016b.) After the 1967 war, the Israeli government expanded the municipal boundaries of Jerusalem to include $71 \mathrm{~km}^{2}$ of the West Bank. The new boundaries were traced to permit 'a maximum of land with a minimum of Arabs' (Benvenisti, 1995: 
53)-i.e. to allow the city to expand on a metropolitan scale through the annexation of vast tracts of empty land beyond the narrow $\left(6.5 \mathrm{~km}^{2}\right)$ limits of the Jordanian municipality of Jerusalem, while at the same time leaving densely inhabited Palestinian suburbs such as Abu Dis and el-Eizariya outside the city limits. The expansion of the municipal boundaries represented an administrative fact on the ground intended to foreclose the possibility of a future territorial compromise being forced on Jerusalem. This also dictated the choice of the 'dispersed' model of urban development favoured by the government and the Ministry of Housing, which aimed at the rapid mobilization of resources to build Jerusalem's so-called 'new neighbourhoods' (French Hill, Gilo, Ramot, Neve Ya'akov, East Talpiot and Pisgat Ze'ev) on greenfield sites. The dispersed model was preferred to the 'compact' city model, which had been advanced in the informal master plan for possible future reunification of the city, drafted by municipal planners in the years before 1967 (Schweid, 1986; Faludi, 1997).

The same underlying principle (to establish a large unified city with a dominant Jewish majority) continued to guide Israel's planning policy over subsequent decades, resulting not only in a marked gap between communities in terms of housing, services provision and infrastructure investments, but also in a chaotic expansion of the urban fabric-indeed, no comprehensive plan for the city of Jerusalem has been legally approved since 1959. The most recent proposal for a new outline plan, the Jerusalem Master Plan 2000' (JMPD, 2004), explicitly emphasized the need to maintain a Jewish majority in the city, expressed in terms of a population objective of $60 \%$ Jewish to $40 \%$ Palestinian-in itself a shift from the original post-1967 70\%/30\% ratio. In order to maintain this ratio, the plan allocated a limited amount of land for the expansion of Palestinian neighbourhoods. Still, even this relatively modest increase proved to be controversial. The plan was presented in an initial version in 2004, and was eventually approved in 2007. However, the Israeli interior minister effectively vetoed the plan, claiming it discriminated against Israelis in favour of Palestinians (Rokem, 2013: 9).

Consequently, as Faludi (1997: 83) notes, Israeli planning authorities have operated in Jerusalem with a strong sense of purpose, but without adopting a formal or explicit planning doctrine. Echoing Faludi's remarks, a senior planner (formerly policy director of the Jerusalem Municipality Planning Department) observes:

Jerusalem grew during the last 40 years, not in a systematic way as towns are growing, gradually from one point to another; it was jumping to the edge of the boundaries of the boundaries ... If it was to remain to the planners, they probably would not decide to [build] in the south Gilo somewhere, but to grow [the city] gradually, step by step, towards that. ${ }^{2}$

In the same vein, a senior planner in the Jewish settlement of Ma'ale Adumim (a dormitory town of about 40,000 residents located about $7 \mathrm{~km}$ east of the Old City of Jerusalem) comments:

I think that Jerusalem lacks a lot in planning: it does not have a general view. After 1967, the Ministry of Housing and the government tried to achieve certain political goals in Jerusalem ... I don't think that there was really [much thought] about ... how this town will function. ${ }^{3}$

Examination of the planning system at the metropolitan scale-where the demographic weight of the Palestinian community is greater than in the municipality of Jerusalem (see Allegra, 2013: 504-06) - offers an even better illustration of the 
distortions imposed on the statutory tools for urban and regional planning. The metropolitan area of the city is by and large a functional urban region (despite the existence of severe limitations to Palestinian freedom of movement); however, this region is effectively split in two halves in jurisdictional and administrative terms. The first is represented by the Israeli Jerusalem District and the second by the Israeli Civil Administration. The Jerusalem District is an administrative planning region including the Jerusalem municipality and the area that lies westward. Planning in this area is the responsibility of the Jerusalem District Planning Committee and falls within the provision of TAMAM 30/1 (Ministry of Interior, 2013), the current statutory plan for the district (see Figure. 1).

Much of the functional region of the city, however, lies outside the Jerusalem District boundaries on the east side of the 1967 'Green Line'. The area lying north, east and west of the municipality of Jerusalem is placed under the supervision of the Civil Administration, a division of the Israeli Ministry of Defence in charge of administering the West Bank. Its planning system is based on the pre-1967 Jordanian law, as amended by the Israeli military authorities. In this area we find a number of Palestinian and Jewish communities, including a few relatively large urban centres such as Ramallah, Bethlehem, Givat Ze'ev and Ma'ale Adumim. Further elements have contributed over time to the fragmentation and stratification of the planning system, including notably: the implementation of the Oslo agreements which introduced at least four main different governance models operating on an archipelago of separate administrative areas in the West Bank; and the construction of the so-called 'separation barrier' begun in 2003.

The areas of the West Bank under the authority of the Israeli Civil Administration enjoy a differentiated degree of informal integration into the Israeli planning system. Planning schemes for large Jewish settlements such as Ma'ale Adumim are largely (albeit informally) part of a metropolitan understanding of a Jewish 'Greater Jerusalem'. Planning documents, such as for example the $2006 \mathrm{Ma}$ 'ale Adumim regional master plan (see Figure 1), make it clear that Israeli planning for the actual Jerusalem functional region is not limited to the territorial scope of Jerusalem District plans like TAMAM $30 / 1$.

This fundamental ambiguity is implicitly acknowledged by the recent emergence of planning concepts that seek to operationalize the political notion of 'Greater Jerusalem'. Since 2009, for example, the Jerusalem Institute for Israel Studies (JIIS, the quasi-official municipal research institute on planning issues in Jerusalem) has added to its yearly Jerusalem Statistical Yearbook a section presenting data on the so-called 'Jerusalem Region', which includes the municipality of Jerusalem and its Jewish hinterland on both sides of the 'Green Line', while at the same time excluding Palestinian localities in the West Bank (Choshen and Korach, 2014: 95; JIIS, 2014). As one of its own planning staff remarked, JIIS consciously decided not to publish data on the Palestinian population in the metropolitan area. ${ }^{4}$

The constraints placed by political imperatives on the development of the urban fabric are most evident in the field of housing policy-critical for the maintenance of an 'appropriate' demographic balance between the two communities. Distortions in data collection such as those underlying the concept of a 'Jerusalem Region' reflect Israeli concerns for the 'worsening' demographic balance regarding the Palestinian population both within and outside the municipal boundaries of the city. At the end of 2013 , the population of the municipality of Jerusalem numbered 829,900. The Jewish population was 509,600 (61.4\%), while there were 320,300 non-Jewish residents (38.6\%) (CBS, 2013). By not considering Palestinian localities in the West Bank, the JIIS' Jerusalem Region incorporates an additional 495,000 Jewish residents, but only 6,500 


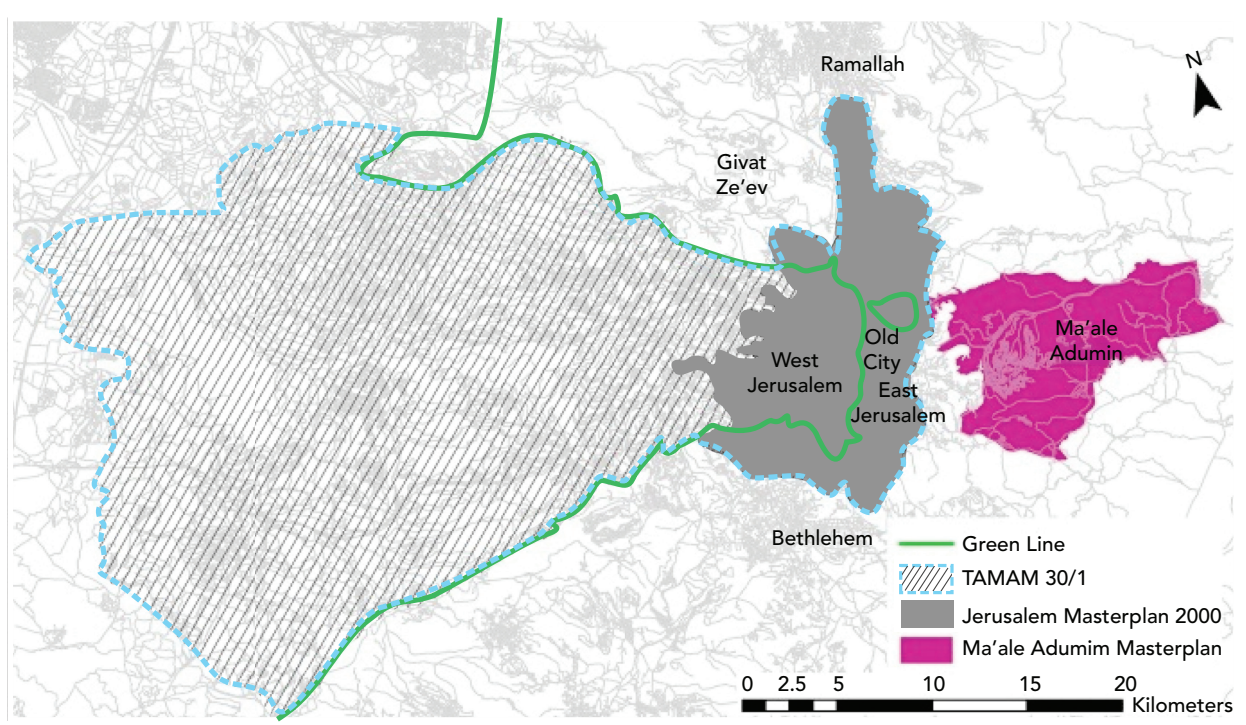

FIGURE 1 Greater Jerusalem map, reproducing the Jerusalem regional masterplan (TAMAM 30/1), the Jerusalem masterplan 2000 and Ma'ale Adumim masterplan (map created by authors and designed by Sadaf Sultan Khan)

Palestinians (i.e. the residents of Abu Gosh, an Arab-Israeli village located $10 \mathrm{~km}$ west of Jerusalem). This is clearly an optical illusion: estimates roughly based on the territorial notion of a Jerusalem Region showed that, when Palestinian localities are included, the population of the area is about two million people (with a slight majority of Palestinian residents) (Allegra, 2013: 504-06), distributed along two axes crossing in Jerusalem-what Noam Shoval (2007: 96) calls the 'Metropolitan X': a Palestinian north-south axis stretching from Ramallah to Bethlehem and an Israeli east-west axis stretching between Ma'ale Adumim and Modi'in. So far our analysis has presented Jerusalem's multifaceted geopolitical constraints; in next sections we will focus on how the city's planners deal with the implications of working within such a complex reality.

\section{Planning in turbulent times}

In this section we discuss Israeli planners' perception of the entanglement of political and planning issues, and their strategies and agency in relation to urban development. A few considerations are in order before going further. Our discussion is mainly based on interviews with Israeli and Palestinian planners undertaken between 2010 and 2013. While our original focus was on substantive urban issues, our engagement with respondents and the empirical material has pushed us to explore the subjectivity and the agency of planners themselves. Methodologically, the organization of fieldwork and interpretation of the data followed the same inductive pattern, through coding, memo writing and theoretical sampling.

The discussion presented in this article is based on selected interviews with Israeli planners (including two Palestinians with Israeli nationality); we decided to focus on Israeli planners because in Jerusalem substantial constraints are placed on the participation of non-Israelis (i.e. on Palestinian planners without Israeli nationality) in the planning process and on political mobilization in general. In consideration of this fact-and of the limited space available to develop our analysis-we chose to discuss a restricted but more homogeneous group of respondents. Our respondents work(ed) in either municipal and governmental administrative offices and bodies, or human rightsfocused NGOs (such as Bimkom, Peace Now, B'Tselem and Ir Amim, among others). 
To frame our discussion, we will refer to these two categories as 'mainstream' and 'activist' planners respectively. Even in the polarized environment of Jerusalem, however, the two categories cannot be neatly separated: 'mainstream' planners sometimes become stern critics of the same policies they have contributed to implementing, or they refrain from making career choices that would require them to work in specific areas or fields. Similarly, 'activist' planners work in West Jerusalem with the same municipal officers whose policies in East Jerusalem they criticize. And in each case, criticism (and endorsement) of Israeli official policies varies in degree and nature. Retrospectively, however, we found that this distinction tends to reflect the existence of different narratives about planning developed by the two groups.

The impact of politics on urban planning issues

How do planners in Jerusalem see the relation between planning and politics? On the surface, a rather striking unanimity seems to characterize the local planning community. Jerusalemite planners seem to be perfectly conscious of the deep politicization of urban issues; everyone can mention episodes in which planners have 'lost' the battle to politicians, or in which the lack of proper planning and the distortions of statutory and developmental tools negatively affected the local community.

The professionals working in the various branches of Israeli administrationwho we have called 'mainstream' planners-are almost unanimous in lamenting the absence in Jerusalem of what Faludi (1997) would consider an explicit 'planning doctrine'. After 1967, crucial decisions on the future development of the city were 'imposed on the planners to handle ... The major decisions are political decisions and the planners have to cope with it'. ${ }^{5}$ This is further reflected in the words of the Jerusalem Municipality Planning Department's boss, voicing his opinion about the option of promoting plans in Jerusalem's Palestinian areas: 'What are my chances of moving the plan forward in the current municipality? ... not great [because of] lack of political interest' on the part of the municipality. ${ }^{6}$

Activist planners know only too well the difficulties inherent in attempting to plan in Palestinian neighbourhoods, and they certainly agree on the impact of the planning system's entrenched politicization. Indeed, much of the activity of organizations such as Bimkom, Peace Now, B'Tselem and Ir Amim revolves around highlighting the distortions of local planning policies and monitoring their (negative) results on the local community (see e.g. Cohen-Bar and Kronish, 2013; El-Atrash, 2015).

Similarly, on the surface planners seem to share the idea that adherence to a set of 'good planning practices' constitutes an essential requirement for implementing meaningful and effective planning intervention in the city. NGOs involved in planning initiatives seem to invariably adopt participative and deliberative practices in their modus operandi (Bimkom, 2006; Rokem et al., 2009; El-Atrash, 2015), but even mainstream planning institutions seem to have adopted the now-standard references to participatory practices, multidisciplinarity and multiculturalism as the base for a comprehensive approach to urban issues and the creation of positive relations with stakeholders in general. This is reflected in the quote below, from a 2010 JIIS study on the Kidron Valley (a north-south strip separating the Old City from the Mount of Olives):

a strong emphasis was placed on involving [Palestinian] residents of the area in the process. The researchers met with representatives of the residents of all the neighborhoods included in the research area ... The multidisciplinary team included researchers and planners from numerous fields, including 
Arab researchers who are thoroughly familiar with the area. We owe the latter particular thanks for enabling the entire team to gain a closer acquaintance with the living conditions and physical state of the neighborhoods (Kimhi, 2010: 12).

Such unanimity, however, is more apparent than real. If all the planners in Jerusalem concur on the politicization of planning, their interpretations of the relation between planning and politics diverge radically, largely reflecting a 'mainstream'/ 'activist' divide. Mainstream planners tend to see the relation between planning and politics in antagonistic terms: political obstacles constitute a burden imposed by the conflict as a whole on the metropolitan area-and on their efforts as professionals. Indeed, many planners seem to believe that a structural incompatibility exists between planning and politics. By creating balanced development schemes, planning would irremediably conflict with the political process by setting preconditions to the negotiations. ${ }^{7}$ The ubiquitous politicization of urban issues would therefore represent the antithesis of the positive atmosphere required for productive planning discussions. As a senior planner in the Jerusalem municipality notes in explaining the lack of development in Palestinian areas:

When you negotiate with the Arab sector there is a clear difference in perception and it's much harder to reach a solution ... they don't agree even when you reach a solution for $90 \%$ of the houses becoming part of the plan and another $10 \%$ illegally built having to be demolished. It's a $100 \%$ win-win solution or nothing. ${ }^{8}$

The politics of the Israeli-Palestinian conflict also creates distortions in the agenda of urban development. One of our respondents, elaborating on the 'conflict between urban goals and government goals', notes:

Every time a developer wants to develop something in the city centre ... [the municipality] would tell him to develop their residences [for the Jewish population]. Why? Because they want to keep the demographic balance.

Residences, residences, residences ... and then the city centre is not functioning because every time they develop residences instead of services, arts, museums, employment, as it should be. ${ }^{9}$

The dichotomy between 'urban goals and government goals' is ultimately founded on the idea that planning and political considerations are separable. Indeed, in an effort to come to terms with the partisan nature of planning policies in Jerusalem-and, sometimes, to minimize their own involvement in political controversies-many of the mainstream planners seem to adopt the strategy described by Morley and Shachar (1986: 45), namely to base their activity on a discourse that emphasizes the technical and ultimately objective nature of planning knowledge and methodologies.

This strategy is enacted by creating multiple layers of professional and institutional boundaries that separate planning activity from the surrounding political context, which ultimately create and maintain a 'safe space' for the planner to act in conformity with his or her professional training and ethics. A first layer consists of a "psychological separation of an administrative "me" from a political "them"” (Bollens, 2000: 109). While our respondents often spontaneously declared their political preferences-

7 Interview with planner, International Peace and Cooperation Center (IPCC), Jerusalem, November 2010. See also Bollens (2000: 153-4)

8 Interview with senior urban planner, Jerusalem Municipality Planning Department, Jerusalem, June 2013.

9 Interview with planner, Jerusalem Institute for Israeli Studies, February 2010). 
usually in a convoluted manner (e.g. 'I am not known as very right wing-on the contrary'10)-they did so only to immediately distance themselves from the entanglements of politics by unequivocally stating their adherence to professional and ethical standards. Indeed, our respondents regularly emphasized their strictly professional role in the planning process: as one of them put it: 'I am not a politician ... The attitude of this office is very professional; we are not into political issues' ${ }^{11}$ Some of the respondents articulated this separation by referring to the different stages of the planning process: planners begin their work after politicians have already created the set of opportunities and constraints allowing the former to act, so that what's left for the planners in many cases is to ensure that political deliberations are translated on the ground in a professional way. For others, planners and politicians belong to separate species altogether-some of our respondents went so far as to imply that an agreement about major planning decisions among members of the planning community would be relatively easy to reach, irrespective of individuals' political views or ethnic background. ${ }^{12}$

The second layer of separation between politics and planning is provided by the methodological apparatus that makes up the planning profession: a code of conduct and a set of technical tools that would enable the avoidance of political debates on issues such as sovereignty and self-determination, democracy and human rights, and instead allow a focus on the apparently 'non-political' issues inherent in the daily life of individuals and communities across the city. Many planners seem to believe that, to a certain extent at least, the use of specific planning instruments-such as the 'potential model' of placing infrastructures to serve both communities in areas where the potential for conflict is highest-would allow bypassing political issues and even have an inherent value in terms of conflict management. ${ }^{13}$ Reference to methodology, technical tools and professional standards is deemed to provide planners with a separate space, a space where they can deal with contentious issues as purely urban issues, and where professional expertise can be deployed in a relatively uncontroversial way. Or, to put it differently, whatever the (lamentable) political situation, the stakeholders can achieve tangible benefit from the use of the planners' professional toolbox. A JIIS planner expresses this concept as follows:

I am speaking about the basic urban level of services, employment, transportation ... I think that the basis for a joint life does not have to include any political restructuring ... I think that things can advance even without any change of political framework. I know that the facts in the last 40 years are against what I am saying, but I think that [there have been some advances]. ${ }^{14}$

The logic of 'incompatibility' between planning and politics enunciated by mainstream planners is turned upside down by activist planners. While they also express their frustration in confronting the urban reality of Jerusalem, they see the distortions of urban development not as the unfortunate consequence of the prevalence of political considerations, but rather the direct consequence of the partisan nature of the local planning system - from the ethno-national demographic imperatives informing planning decisions to the collusion between politicians, government officials and the Jewish settlers. The impossibility of addressing pressing urban issues does not depend on political constraints placed on professional planning practice, but rather on the overall

10 Interview with senior researcher, Jerusalem Institute for Israeli Studies, November 2010.

11 Interview with head of Jerusalem District Office, Ministry of Housing, November 2010.

12 Interview with chief architect, Ma'ale Adumim Planning Team, Tel Aviv, November 2010.

13 Interviews with senior researcher, Jerusalem Institute for Israeli Studies, November 2010; head of Jerusalem District Office, Ministry of Housing, November 2010; head of Program Implementation Department, Ministry of Housing, Jerusalem, November 2011. See also Bollens (2000: 148).

14 Interview with planner, Jerusalem Institute for Israeli Studies, Jerusalem, February 2010. 
coherence between planning and politics, and on the consensus among politicians, bureaucrats and professionals about the fundamental goals and principles of urban policy. ${ }^{15}$ Hence, the main source of frustration for activist planners is not the feeling that political factors limit their role as professionals: instead they perceive themselves as waging a struggle against the whole planning system-a struggle in which 'counterplanning' activities require huge efforts but only bring about minimal results.

In a more subtle way, the ambiguous and artificial separation between planning and politics is widely perceived by 'activist' planners as an effective rhetorical tool to avoid debating pressing urban issues and prevent the submission of planning objections or filing petitions to courts:

The planners in the offices, they say, 'this is politics, don't talk to us here in this committee about politics, we are talking about planning'. ${ }^{16}$

I am not very optimistic about [going to court] ... For example, the petition against E-1 [an area between the city of Jerusalem and the settlement of Ma'ale Adumim; Israeli development plans for the area are widely seen by the Palestinians and international community as a major obstacle to a two-state solution-see Allegra (2014)] in 1998 was rejected on the ground that [it was] a general petition that deals with issues that are primarily political in nature. Now, you can argue this [about almost] everything in the West Bank, so that's why we actually avoid as much as possible anything that can hit on a political argumentation ... But still, if they want they can always say it. ${ }^{17}$

In this context, political considerations are a crucial factor in the evaluation of planners' roles in Jerusalem. Mainstream planners' arguments about defending their neutrality through commitment to professional standards so as to maintain a balanced role in dealing with urban issues is widely considered by activists as an attempt at selfdeception or, worse, as a rhetorical device designed to hide their complicity with the system:

Planners want to get jobs. They are part of the political system, of the power relationship... There are very few planners who refuse to plan in the occupied territories, most of them hide behind that excuse, 'We are trying to be [neutral]'. The fact that you [make] that plan is political ... otherwise you should refuse. If you don't refuse, you become part of the process. ${ }^{18}$

Some of our respondents had left positions in Israeli planning offices, precisely because of their uneasiness with the political environment and the overall direction of municipal policies. ${ }^{19}$ Commenting on her earlier career in the planning administration, one individual concluded that she no longer felt comfortable representing the municipal authorities, and this motivated her decision to work freelance, with the option of selecting projects in keeping with her political views. ${ }^{20}$ Similarly, another prominent figure in the Jerusalem planning establishment who had 'opted out' for political reasons was Sarah Kaminker (see Forester et al., 2001: 115-38).

15 Interview with planner, Bimkom, Jerusalem, February 2010 and July 2012; see also Kaminker (1997).

Interview with planner, Bimkom, Jerusalem, February 2010 and July 2012.

Interview with researcher, Bimkom, Tel Aviv, February 2010.

Interview with former deputy mayor, East Jerusalem portfolio, November 2010

19 Interviews with former Jerusalem city engineer and current activist planner, Tel Aviv, February 2010; and former deputy mayor, East Jerusalem portfolio, November 2010.

20 Interview with private consultant planner, formerly deputy director general for the Israel Government Tourist Corporation and director at Jerusalem Municipality Planning Department, May 2012. 
The same considerations on the position of the planner vis-à-vis the political system are part of an ongoing debate among activist planners about the possibility of 'working the system'.

From the start we had an internal debate [about whether] we should actively engage in the planning process or remain an outside critical voice opposing unjust planning and violation of human rights ... When we actively plan, we become part of the disease and can't take a more external critical position. ${ }^{21}$

Ultimately, the controversy surrounds the very meaning of planning practices. Contrary to the largely procedural (if sometimes participative) neutral approach enunciated by mainstream planners, for activists, professional techniques and methodologies have a less straightforward role in the planning process. In the report on the Kaminker Project-a deliberative planning initiative carried out by the Israeli NGO Bimkom in the Palestinian neighbourhood of Isawiya-this double role is clearly enunciated: on one hand, the document states that in Jerusalem 'all too often political and economic interests drive planning decisions' while ' $[\mathrm{t}]$ he planning decisions of the Kaminker team were based ... on objective planning criteria, namely, the needs and constraints of Issawiya residents'; on the other hand, Bimkom's planning intervention in Isawiya had an inherent, broader political goal, aiming to serve 'as a tool to foster equality and promote co-existence between Arab and Jewish populations' (Bimkom, 2006: 4).

- $\quad$ 'Good planning practices' and the contextual nature of planners' agency

The quotes above introduce the second crucial theme of this article. How is it possible for planners in Jerusalem to have an impact on urban issues? Do planners have any agency at all in the contested city of Jerusalem? And what is the role of adherence to a set of 'good planning practices in this respect?

The starting point of our discussion is the conventional wisdom that in Jerusalem planning plays a largely subordinate role; in other words, planning in Jerusalem is either irrelevant (because political considerations, rather than planning arguments and models, dictate development in the city) or purely instrumental in the face of politics, i.e. planning is simply 'war carried out by other means' (Coon, 1992: 210) - the argument echoes the position of some post-colonial theorists (Porter, 2010, e.g.) who consider planning as inherently geared towards the exclusion and dispossession of the colonized. It is certainly not our intention to deny the partisan nature of the planning interventions that have marked Jerusalem's urban development under Israeli rule over the last decades: the growth of the city and the structure of the planning system have been profoundly affected by the lack of representation of the Palestinian population and the partisan nature of Israeli policies. From this point of view, the case of Jerusalem has often been cited to support the view that 'good planning practices' per se do not constitute an antidote to the status quo and can even aggravate the conflicts they are supposed to minimize-what Dumper (1997) called the 'central paradox' of planning in the city (see also Bollens, 2000: 12).

Acknowledging partisanship, however, does not necessarily mean subscribing to the idea that the relation between planning and politics is hierarchical. The line between planning and politics is openly and constantly blurred in Jerusalem, so that in a sense it is paradoxical to frame the relation between the two in terms of a clearcut hierarchy. Dumper's (1997) paradox represents a first implicit acknowledgement of the fact that the very idea of 'good planning practices'-collecting detailed first- 
hand knowledge of the urban environment, adopting sophisticated technical tools, involving stakeholders, and so forth-should be problematized by contextualizing and historicizing our exploration of the planning process. Empirically, the impact of planners on major urban issues should not be measured against the yardstick of a planning handbook, but rather in a more holistic manner: to this end, planners should be considered as fully fledged actors, who participate in the policy process by virtue of their professional status, but whose role is not necessarily limited to a technical contribution.

Jerusalem offers multiple examples of how planning and political arguments might overlap, and how planners' agency might surface in unexpected ways. To be sure, Jerusalemite planners face issues that go well beyond the narrow realm of planning and their professional skills and training. Crucially, however, planners' inclusion in the policy process instead involves practical judgments and a strategic use of their professional knowledge and status (Flyvbjerg, 1998b; Wagenaar, 2004) in the planning process itself. As David Best (a mainstream planner working in East Jerusalem after 1967) notes, working as a planner does not simply entail the mobilization of technical knowledge, but rather the display of a wider range of skills including lobbying, creating and maintaining access to influential individuals and institutions, and manipulating clients and public opinion (Forester et al., 2001: 57-64). In Best's words, the planner should 'try to get people to believe that they have arrived at conclusions which they feel is right ... It's a question of psychology, backed up by a lot of information and knowledge' (ibid.: 61-3). The description by Thomas Leitersdorf, chief architect of the team responsible for planning Ma'ale Adumim, of the meeting during which the final location of the settlement was chosen, offers an opportunity to reflect on these dynamics:

When we put the alternatives to the Ministerial Committee for Settlement [the body charged with the approval of the establishment of new settlements], headed at the time by Ariel Sharon, the only questions asked were: 'Which of the alternative locations has better control over the main routes?' And 'which town has a better chance to grow quickly and offer qualities that would make it competitive with Jerusalem?' I replied that according to these criteria the ideal location would be location A [the present site of Ma'ale Adumim] ... At that moment Sharon rose and declared, without consulting the Committee, that 'the State of Israel decides on location A' (Tamir-Tawil, 2003: 153-4).

On the surface, this vignette seems a straightforward case of top-down politicostrategic decision-making. The notorious 'hawk', Likud member Ariel Sharon (later prime minister of Israel), is apparently the only relevant player on the scene: the planner's subordinate position is clear as he limits himself to answer the politician's specific questions - the rest of the committee is simply silent. However, if we dig beneath the surface, this picture reveals a hidden complexity. First, the (four) locations on which Sharon was asking the planner's opinion had been previously selected by another planning team more than a year before, during the last months of Yitzhak Rabin's first tenure as prime minister-Sharon himself therefore acted (to a certain extent at least) within the boundaries determined by planners. Second, interviews with members of the Ma'ale Adumim planning team reveal that they wanted to change the location of the settlement to location A prior to the meeting of the committee. ${ }^{22}$ This means that Sharon, by interrogating planners' (supposedly) neutral expertise, ended up 
choosing the location that the planners had already selected as the best possible option. What is important here is not so much planners' motivations for choosing location A, or the possible conflicts between politician and planner, but rather the appreciation of the fact that the decision-making landscape is significantly more blurred than one might sometimes assume-and that planners, like any other actor, can exert their influence on the planning process by strategically interpreting the dynamics of decision making.

To relate to the distinction introduced earlier between 'politics in planning' and 'politics of planning', planners operate both as 'post-empiricist experts' (Fischer, 2009) contributing to the policy process through their mastery of technical knowledge and their ability as mediators, and as agents of political mobilization in the broader context of a given urban reality. Mainstream planners might wish for an environment where their professional lives are made easier by the relaxation of political tensions, and where urban issues are treated following planning handbooks more closely. This does not mean, however, that planning and political arguments are invariably at war. As one of our respondents notes, technical arguments could be mobilized in support of the construction of suburban settlements like Ma'ale Adumim, alleviating the demographic pressure on the overcrowded city of Jerusalem. ${ }^{23}$ Furthermore, planners do have political worldviews, which sometimes harmonize with decisions taken by politicians; this is the case, for example, in the period immediately following the reunification of Jerusalem-in Israel Kimhi's words, 'a glorious time' for Israeli planners (Bollens, 2000: 109) given the once in a lifetime opportunity to reconfigure 'Jerusalem' from a split city into one urban core.

The case of activist planners offers us yet another example in this respect. As two Israeli researchers observe in their study of Bimkom's deliberative planning initiative in the East Jerusalem Palestinian neighbourhood of Isawiya, 'Had we chosen to measure Bimkom's planning process against any ideal model of deliberative planning, we would have to deem it a failure' (Ron and Cohen-Blankshtain, 2011: 646), because of the political limitations inherent in the development of the process and, ultimately, the impossibility of getting any plan approved by hostile local planning commissions. Still, precisely because the chances of achieving tangible results through the planning system remain very low, political mobilization becomes the ultimate goal of planning practices. Deliberative planning practice can be understood 'as a form of political representation that competes with other forms of representation' (ibid.: 637). As a Bimkom architect and planner notes with respect to a petition against house demolitions in Palestinian neighbourhoods: 'We don't believe that our petition ... will stop demolitions, but we want to raise awareness' (interview with Bimkom planner, Jerusalem, February 2010). It might well be true, as Alfasi (2003) and Martens (2005) have argued in relation to the Israeli case, that participatory practices do not necessarily make the planning process more democratic if more structural reforms of the planning system are not implemented. However, the practices of activist planners also quite clearly function as a vehicle for addressing urban issues in a broader holistic way (Yacobi, 2007).

As such, activists' deliberative planning practices (although partial and most likely doomed to failure) hold value in their promotion of a more democratic approach to planning even in such contested cities as Jerusalem (El-Atrash, 2015: 50). In this respect, the case of Jerusalem is also instructive in that it shows that planning initiatives can sometimes have an impact in their challenges to dominant approaches. First, and most obviously, from time to time plans initiated by activist planners or Palestinian residents unexpectedly make it through the Israeli planning commissions. The case studies examined in the recently released UN-Habitat report on Jerusalem (ibid.) presents some examples in this respect. Even more surprising has been the recent 
approval by the Jerusalem District Planning and Building Committee of a plan for the construction of 2,500 housing units in the Palestinian neighbourhood of Jabal Mukaber, initiated by Israeli-Palestinian architect Senan Abdelqader on behalf of the residents (Hasson, 2014). Needless to say, many doubts remain about the future implementation of this project. Also, a more detailed analysis of the plan would be needed to assess how many of the 2,500 planned housing units represent new construction, rather than the retrospective approval of existing buildings.

Second, individual uncoordinated planning initiatives can incrementally create the conditions for broader political changes. As Braier (2013) has argued in her study of Jabal Mukaber, where several NGOs have been especially active over the last 15 years, independent zoning plans submitted by Palestinians to Israeli commissions represent a form of 'quiet encroachment' (Bayat, 2013) — or, as James Holston (2008) would put it, 'insurgent planning'-see also Sandercock (1998). In other words, these initiativessmall-scale plans submitted by individual residents in order to protect their properties from the threat of demolition or to allow for small improvements-are not born out of political opposition to the system nor do they offer a comprehensive planning alternative to major urban issues; nevertheless, the cumulative nature of these efforts constitutes an inherent challenge to Israeli sovereignty as expressed in local planning policies.

\section{Conclusion}

As far as the relation between planning and politics is concerned, Jerusalem represents a rather exceptional case study (Rokem, 2016a). However, we argue that the examination of such an extraordinary case study can offer some suggestions regarding how to conceptualize relations between planning, conflicts and power. At the same time, it makes the case for a more nuanced and non-hierarchical understanding of these relations.

In the first place, Jerusalem offers a stark reminder of how urban and planning issues are more broadly political and social issues-it represents an 'extreme case' in this respect. This is where communicative scholars' emphasis on planning as a set of procedures to deal with politics (or with 'politics in planning') falls short of connecting the internal dynamics of the planning process with broader socio-political realities (the 'politics of planning'). This is also the case for any other procedural definition of 'good planning practices', irrespective of whether 'good' is understood in terms of planning possessing inherently progressive potential in delivering rational/efficient solutions, or in a more democratic/participative fashion.

In Jerusalem, the problem is not only that mediators who 'stand in connection to all sides for justice's sake' (Forester, 2009: 5) or power-savvy deliberative practitioners (Forester, 1999) cannot be found anywhere because of the polarized atmosphere of the city, but also that the planners' agency can only be assessed in relation to the sociopolitical environment in which they operate. It is in this respect that Jerusalem represents a 'critical case'. The acknowledgement of the deep politicization of planning issues in Jerusalem does not simply restrict the role of planners to either irrelevance or complicity: rather, it offers us an appropriate yardstick for assessing their agency within what can be framed as the local 'planning politics nexus'-the relation between planning and politics, as a non-hierarchical set of interactions, negotiated within the specific historical, geographical, legal and cultural contexts in which they develop. Planners' agency should not be judged simply by 'how much planning' they can inject into urban development, but by their more general contribution to the policy process. The case of Jerusalem demonstrates that, even in such a polarized environment, planners' agency can surface in many different ways, inside and outside the institutional boundaries of the planning process. 
Jonathan Rokem, The Bartlett School of Architecture, University College London, 140 Hampstead Road, London NW1 2BX, UK, jonathanrock1@gmail.com

Marco Allegra, Instituto de Ciências Sociais, Universidade de Lisboa, Av. Professor Aníbal de Bettencourt 9, 1600-189 Lisboa, Portugal; and Instituto Universitário de lisboa (ISCTE-IUL), Centro de Investigação e Estudos de Sociologia, Lisboa, Portugal, marco.allegra@ymail.com

\section{References}

Alfasi, N. (2003) Is public participation making urban planning more democratic? The Israeli experience. Planning Theory \& Practice 4.2, 185-202.

Allegra, M. (2013) The politics of suburbia: Israel's settlement policy and the production of space in the metropolitan area of Jerusalem. Environment and Planning A 45.3, 497-516.

Allegra, M. (2014) E-1, or how I learned to stop worrying about the two-state solution. Open Democracy [WWW document]. URL https://www.opendemocracy.net/ arab-awakening/marco-allegra/e1-or-how-i-learnedto-stop-worrying-about-twostate-solution (accessed 5 June 2016).

Allegra, M., A. Casaglia and J. Rokem (2012) The political geographies of urban polarization: a critical review of research on divided cities. Geography Compass 6.9, 560-74.

Anderson, J. (2008) From empires to ethno-national conflicts: a framework for studying 'divided cities' in 'contested states'. Divided Cities/Contested States working paper [WWW document]. URL http://www. conflictincities.org/workingpapers.html (accessed 10 August 2015).

Bayat, A. (2013) Life as politics: how ordinary people change the Middle East. Stanford University Press, Stanford, CA.

Beaumont, J. and M. Loopmans (2008) Towards radicalized communicative rationality: resident involvement and urban democracy in Rotterdam and Antwerp. International Journal of Urban and Regional Research 32.1, 95-113

Benvenisti, M. (1995) Intimate enemies: Jews and Arabs in a shared land. University of California Press, Berkeley, CA.

Bimkom (2006) The Kaminker project in the East Jerusalem neighborhood of Issawiya. Report of the first two years of activity. Bimkom, Jerusalem.

Bollens, S.A. (2000) On narrow ground: urban policy and ethnic conflict in Jerusalem and Belfast. State University of New York Press, Albany.

Bond, S. (2011) Negotiating a 'democratic ethos': moving beyond the agonistic-communicative divide. Planning Theory 10.2, 161-86.

Braier, M. (2013) Zones of transformation? Informal construction and independent zoning plans in East Jerusalem. Environment and Planning A 45.11, 2700-16.

Calame, J. and E. Charlesworth (2011) Divided cities: Belfast, Beirut, Jerusalem, Mostar, and Nicosia. University of Pennsylvania Press, Philadelphia.

CBS (Central Bureau of Statistics) (2013) Statistical abstract of Israel (vol. 64). Central Bureau of Statistics, Jerusalem.

Choshen, M. and M. Korach (2014) Facts and trends: the state of the city and changing trends. Jerusalem Institute for Israel Studies, Jerusalem.

Cohen-Bar, E. and S. Kronish (2013) Survey of Palestinian neighborhoods in East Jerusalem: planning problems and opportunities. Bimkom, Jerusalem.

Coon, A. (1992) Town planning under military occupation: an examination of the law and practice of town planning in the Occupied West Bank. Dartmouth, Aldershot.

Dumper, M. (1997) The politics of Jerusalem since 1967. Colombia University Press, New York.
Dumper, M. (2014) Jerusalem unbound: geography, history and the future of the holy city. Colombia University Press, New York.

El-Atrash, A. (2015) Right to develop: planning Palestinian communities in East Jerusalem. United Nations Human Settlements Programme (UN-Habitat), Jerusalem.

Fainstein, S.S. (2000) New directions in planning theory. Urban Affairs Review 35.4, 451-78.

Fainstein, S.S. (2010) The just city. Cornell University Press, Ithaca, NY and London.

Faludi, A. (1997) A planning doctrine for Jerusalem? International Planning Studies 2.1, 83-102.

Fischer, F. (2009) Democracy and expertise: reorienting policy inquiry. Oxford University Press, Oxford.

Fischer, F. and J. Forester (1993) The argumentative turn in policy and planning. Duke University Press, Durham, NC.

Flyvbjerg, B. (1996) The dark side of planning: rationality and 'Realrationalitat'. In S. Mandelbaum, L. Mazza and R. Burchell (eds.), Explorations in planning theory, Transactions Publishers, New Brunswick, NJ and London.

Flyvbjerg, B. (1998a) Habermas and Foucault: thinkers for civil society? The British Journal of Sociology 49.2 210-33.

Flyvbjerg, B. (1998b) Rationality and power: democracy in practice. University of Chicago Press, Chicago.

Flyvbjerg, B. (2006) Five misunderstandings about casestudy research. Qualitative Inquiry 12.2, 219-45.

Flyvbjerg, B. and T. Richardson (2002) Planning and Foucault: in search of the dark side of planning theory. In P. Allmendinger and M. Tewdwr-Jones (eds.), Planning futures: new directions for planning theory, Routledge, London and New York.

Forester, J. (1982) Planning in the face of power. Journal of the American Planning Association 48.1, 67-80.

Forester, J. (1988) Planning in the face of power. University of California Press, Berkeley, Los Angeles and London.

Forester, J. (1993) The argumentative turn in policy analysis and planning. Duke University Press, Durham, NC and London.

Forester, J. (1999) The deliberative practitioner: encouraging participatory planning processes. MIT Press, Cambridge, MA and London.

Forester, J. (2000) Conservative epistomology, reductive ethics, far too narrow politics: some clarifications in response to Yiftachel and Huxley. International Journal of Urban and Regional Research 24.4, 914-6.

Forester, J. (2009) Dealing with differences: dramas of mediating public disputes. Oxford University Press, Oxford.

Forester, J., R. Fischler and D. Shmueli (2001) Israeli planners and designers: profiles of community builders. State University of New York Press, Albany, NY.

Foucault, M. (1979) Discipline and punish: the birth of the prison. Vintage, New York.

Foucault, M. (1980) Power/knowledge. Selected interviews and other writings 1972-1977. Pantheon, New York.

Foucault, M. (1983) The subject and power. In H.L. Dreyfus and P. Rabinow (eds.), Michel Foucault. Beyond structuralism and hermeneutics, University of Chicago Press, Chicago.

Foucault, M. (1984) Space, knowledge and power. In P. Rabinow (ed.), The Foucault reader: an introduction to Foucault's thought, Pantheon, New York. 
Giddens, A. (1984) The constitution of society: outline of the theory of structuration. University of California Press, Berkeley and Los Angeles.

Gualini, E. (2015) Conflict in the city: democratic, emancipatory-and transformative? In search of the political in planning conflicts. In E. Gualini (ed.), Planning and conflict: critical perspectives on contentious urban developments, Routledge, New York and London.

Habermas, J. (1979) Communication and the evolution of society. Thomas McCarthy (trans.), Beacon Press, Boston, MA.

Habermas, J. (1989) The theory of communicative action. Volume 2, Beacon Press, Boston, MA

Habermas, J. (1990) Moral consciousness and communicative action. MIT Press, Cambridge, MA.

Hasson, N. (2014) Jerusalem approves major housing plan for Arab neighborhood. Haaretz 4 September [WWW document]. URL http://www.haaretz.com/middle-eastnews/.premium-1.613997 (accessed 5 June 2016).

Healey, P. (1992) A planner's day: knowledge and action in communicative practice. Journal of the American Planning Association 58.1, 9-20.

Healey, P. (1996) The communicative turn in planning theory and its implications for spatial strategy formation. Environment and Planning B 23.2, 217-34.

Healey, P. (1997) Collaborative planning: shaping places in fragmented societies. UBC Press, Vancouver.

Healey, P. (2000) Planning theory and urban and regional dynamics: a comment on Yiftachel and Huxley. International Journal of Urban and Regional Research 24.4, 917-21.

Healey, P. (2003) Collaborative planning in perspective. Planning Theory 2.2,101-23.

Healey, P. (2006) Relational complexity and the imaginative power of strategic spatial planning. European Planning Studies 14.4, 525-46.

Healey, P. (2012) Communicative planning: practices, concepts, and rhetorics. In B. Sanyal, L.J. Vale and C. Rosan (eds.), Planning ideas that matter: livability, territoriality, governance, and reflective practice, MIT Press Cambridge, MA

Healey, P. (2013) Circuits of knowledge and techniques: the transnational flow of planning ideas and practices. International Journal of Urban and Regional Research $37.5,1510-26$.

Hillier, J. (2002) Direct action and agonism in democratic planning practice. In P. Allmendinger and M. TewdwrJones (eds.), Planning futures: new directions for planning theory, Routledge, London and New York.

Holston, J. (2008) Insurgent citizenship: disjunctions of democracy and modernity in Brazil. Princeton University Press, Princeton, NJ and Oxford.

Hoppe, R. (1999) Policy analysis, science and politics: from 'speaking truth to power' to 'making sense together'. Science and Public Policy 26.3, 201-10.

Huxley, M. and O. Yiftachel (1998) New paradigm or old myopia? Unsettling the 'communicative turn' in planning theory. Paper presented at the Third Planning Theory Conference, Oxford Brookes University, Oxford, 2-4 April.

Innes, J.E. (1995) Planning theory's emerging paradigm: communicative action and interactive practice. Journal of Planning Education and Research 14.3, 183-9.

Innes, J.E. and D.E. Booher (2014) A turning point for planning theory? Overcoming dividing discourses. Planning Theory 14.2, 195-213.

JIIS (Jerusalem Institute for Israel Studies) (2014) Statistical yearbook of Jerusalem. Volume 28, Jerusalem Institute for Israel Studies, Jerusalem.

JMPD (Jerusalem Municipality Planning Department) (2004) Jerusalem master plan 2000. Jerusalem Municipality Planning Department, Jerusalem.

Kaminker, S. (1997) For Arabs only: building restrictions in East Jerusalem. Journal of Palestine Studies 26.4, 5-16.

Kimhi, I. (2010) The Upper Kidron Valley: conservation and development in the visual basin of the Old City of Jerusalem. Jerusalem Institute for Israel Studies, Jerusalem.
Kliot, N. and Y. Mansfeld (1999) Case studies of conflict and territorial organization in divided cities. Progress in Planning 52.3, 167-225.

Kotek, J. (1999) Divided cities in the European cultural context. Progress in Planning 52.3, 227-37.

Lauria, M. and R. Whelan (1995) Planning theory and political economy: the need for reintegration. Planning Theory 14.1, 8-33.

Martens, K. (2005) Participatory experiments from the bottom up: the role of environmental NGOs and citizen groups. European Journal of Spatial Development 18.1, 2-20.

Ministry of Interior (2013) Jerusalem regional masterplan TAMAM 30/1. Planning Administration, Ministry of Interior, Jerusalem.

Morley, D. and A. Shachar (1986) Planning in turbulence. Magnes Press, Jerusalem.

Mouffe, C. (1999) Deliberative democracy or agonistic pluralism? Social Research 66.3, 745-58.

Mouffe, C. (2000) The democratic paradox. Verso, London.

Mouffe, C. (2005) On the political. Routledge, London and New York.

Porter, L. (2010) Unlearning the colonial cultures of planning. Ashgate Publishing, London.

Pugh, J. (2005) The disciplinary effects of communicative planning in Soufriere, St Lucia: governmentality, hegemony and space-time-politics. Transactions of the Institute of British Geographers 30.3, 307-21.

Purcell, M. (2008) Recapturing democracy: neoliberalization and the struggle for alternative urban futures. Routledge, New York.

Rokem, J. (2013) Politics and conflict in a contested cityurban planning in Jerusalem under Israeli rule. Bulletin du Centre de recherche français à Jérusalem 23.1, 2-12.

Rokem, J. (2016a) Introduction: learning from Jerusalemrethinking urban conflicts in the $21^{\text {st }}$ century. City 20.3, 400-04

Rokem, J. (2016b) Beyond incommensurability: Jerusalem from an ordinary cities perspective. City 20.3, 451-61.

Rokem, J., K. Toufakji and L. Yadin (2009) Toward resolving the planning disparity in Jerusalem: from dissonance to a permanent status destination creating policy options to pave the way to final status. Peace and Democracy Forum and Ir Amim, Jerusalem [WWW document]. URL http://www.pdf-palestine.org/The\%20 Urban\%20Planning\%20Dispute\%20-JPF.pdf (accessed 5 June 2016).

Ron, A. and G. Cohen-Blankshtain (2011) The representative claim of deliberative planning: the case of Isawiyah in East Jerusalem. Environment and Planning D 29.4, 633-42

Rosen, G. and A.B. Shlay (2010) Making place: the shifting Green Line and the development of 'greater' metropolitan Jerusalem. City \& Community 9.4, 358-89

Rosen, G. and A.B. Shlay (2014) Whose right to Jerusalem? International Journal of Urban and Regional Research 38.3, 935-50.

Sandercock, L. (1998) Making the invisible visible: a multicultural planning history. Volume 2, University of California Press, Berkeley, Los Angeles and London.

Schweid, J. (1986) The planning of Jerusalem before and after 1967: attitudes toward uncertainty. In D. Morley and A. Shachar (eds.), Planning in turbulence, Magnes Press, Jerusalem.

Shlay, A.B. and G. Rosen (2015) Jerusalem: the spatial politics of a divided metropolis. Polity Press, Cambridge.

Shoval, N. (2007) Transformation of the urban morphology of Jerusalem: present trends and future scenarios. In S Hasson (eds.), Jerusalem in the future: the challenge of transition, The Floersheimer Institute for Policy Studies, Jerusalem.

Silver, H. (2010) Divided cities in the Middle East. City \& Community 9.4, 345-57.

Silver, H., A. Scott and Y. Kazepov (2010) Participation in urban contention and deliberation. International Journal of Urban and Regional Research 34.3, 453-77. 
Tamir-Tawil, E. (2003) To start a city from scratch: an interview with architect Thomas M. Leitersdorf. In R. Segal and E. Weizman (eds.), A civilian occupation: the politics of Israeli architecture, Verso, London.

Tewdwr-Jones, M. and P. Allmendinger (1998)

Deconstructing communicative rationality: a critique of Habermasian collaborative planning. Environment and Planning A 30.11, 1975-89.

Wagenaar, H. (2004) 'Knowing' the rules: administrative work as practice. Public Administration Review 64.6, 643-56.

Yacobi, H. (2007) The NGOization of space: dilemmas of social change, planning policy, and the Israeli public sphere. Environment and Planning D 25.4, 745-58.
Yiftachel, O. (1998) Planning and social control: exploring the dark side. Journal of Planning Literature 12.4 395-406.

Yiftachel, O. and M. Huxley (2000a) Debating dominance and relevance: notes on the 'communicative turn' in planning theory. International Journal of Urban and Regional Research 24.4, 907-13.

Yiftachel, O. and M. Huxley (2000b) New paradigm or old myopia? Unsettling the communicative turn in planning theory. Journal of Planning Education and Research 19.4, 333-42.

Yiftachel, O. and M. Huxley (2000c) On space, planning and communication: a brief rejoinder. International Journal of Urban and Regional Research 24.4, 922-4. 